\title{
Effects of nutritional education and lifestyle modification on the nutritional status of HIV positive patients: results of a cluster randomized intervention over a period of six months
}

\author{
Germaine Nkengfack ${ }^{1,2,4^{*}}$, Judith Torimiro3 ${ }^{3}$, Jeanne Ngogang ${ }^{3}$ and Heike Englert ${ }^{1,2}$ \\ ${ }^{*}$ Correspondence: mbonguegermaine@yahoo.com \\ ${ }^{1}$ Institute for Social Medicine, Epidemiology and Health Economics, Charité University Medicine Berlin Center, Germany. \\ ${ }^{2}$ Department of Nutrition, University of Applied Sciences, Muenster, Germany. \\ ${ }^{3}$ Faculty of Medicine and Biomedical Sciences, University of Yaoundé I, Yaoundé, Cameroon. \\ ${ }^{4}$ Department of Biomedical Sciences, University of Dschang, Dschang, Cameroon.
}

\begin{abstract}
Background: Effective strategies to improve nutritional status exist, though short-termed and less sustainable for HIV patients in resource limited settings. The aim of this study was to describe the BMI of treatment naïve HIV patients in Yaoundé, Cameroon, and investigate the effects of nutritional education and lifestyle modification on the nutritional status of these patients.

Method: A cluster randomized trial was conducted between 2010 and 2012, and included 5 health facilities, randomized either to the intervention (HIV-Care-Program) or control group (usual care). The HIV-Care-Program consisted of counselling lessons for 6 months on: nutrition, hygiene and coping with stigma and discrimination, complemented by practical activities. Primary outcome variable were change in BMI and serum albumin after 6 months, using analysis of covariance. BMI was calculated from weight (kg) and height $\left(\mathrm{m}^{2}\right)$ and categorized as: underweight (BMI $\left.<18.5\right)$, normal weight $(18.5 \leq \mathrm{BMI} \leq 24.9)$, overweight $(25 \leq \mathrm{BMI} \leq 29.9)$ and obese $\left(\mathrm{BMI} \geq 30 \mathrm{~kg} / \mathrm{m}^{2}\right)$ and used to estimate the prevalence of underweight, normal weight and overweight/obesity. Serum albumin level was determined by the Bromocresol green method.

Results: Of the 201 participants enrolled, 190 were included in the final analysis. $58 \%$ of the study participants in the intervention group were overweight/obese, $40 \%$ normal weight and $2 \%$ underweight. Whereas the distribution in the control group was: $54.5 \%$ overweight/obese, $43.5 \%$ normal weight and $2 \%$ underweight. The BMI in the intervention group was $26.1 \mathrm{~kg} / \mathrm{m}^{2} 95 \% \mathrm{CI}(24.5$, $27.6)$ and $25.8 \mathrm{~kg} / \mathrm{m}^{2} 95 \% \mathrm{CI}(24.5,27.1)$ in the control group. After six months, BMI increased by $1.9 \%$ in the intervention group and decreased by $3 \%$ in the control group $(P=0.088)$. Serum albumin level increased from $2.1 \mathrm{~g} / \mathrm{dl} 95 \% \mathrm{CI}(1.8,2.4)$ to $4.2 \mathrm{~g} / \mathrm{dl} 95 \%$ CI $(3.8,4.5)$ in the intervention group and decreased from $3.4 \mathrm{~g} / \mathrm{dl} 95 \% \mathrm{CI}(3.2,3.7)$ to $3.3 \mathrm{~g} / \mathrm{dl} 95 \%$ CI $(3.0,3.6)$ in the control group $(\mathrm{p}<0.001)$.

Conclusion: The HIV-Care-Program provides an effective low-cost alternative improving serum albumin for treatment naïve HIV patients. The high prevalence of overweight and obesity observed, suggests that qualified dieticians should be involved in the care and management of HIV, and thus future nutritional interventions should also focus on optimising weight in treatment naive patients.
\end{abstract}

Keywords: BMI, HIV, nutritional education, lifestyle, cluster randomization, nutritional status

\section{Introduction}

The HIV virus attacks and impairs the body's natural defence system, making it vulnerable to other diseases and infections. Stimulation of an immune response by HIV infection increases the demand for anabolic energy and associated substrates. This leads to a synergistic vicious cycle of adverse nutritional status and increased predisposition to infection $[1,2]$.

In the past, the HIV infection was commonly associated with wasting $[3,4]$. As the disease progresses, the body metabolism changes, leading to opportunistic conditions such as fever, mouth sores, diarrhoea etc. consequently reducing food intake and weight $[5,6]$.

However, since the introduction of antiretroviral therapy (ARV) and highly active antiretroviral therapy (HAART), important metabolic changes such as insulin resistance, dyslipidemia, as well as overweight and obesity have been observed $[7,8]$. Recently, studies report increasing prevalence of overweight and obesity in HIV patients prior to the initiation of antiretroviral therapy [9-11]. This is an indication that HAARTS is not the single contributing factor to overweight/obesity observed in HIV/AIDS patients, but also inadequate dietary habits and lifestyle [11].

Several studies have confirmed the beneficial effects of these factors in improving nutritional status, though mostly short termed and based on the use of nutritional supplements, which are expensive for HIV patients in resource limitted settings [12-14].

Considering HIV/AIDS as a chronic disease, it could be assumed that combining nutritional education and healthy lifestyle

(c) 2013 Nkengfack et al; licensee Herbert Publications Ltd. This is an Open Access article distributed under the terms of Creative Commons Attribution License (http://creativecommons.org/licenses/by/3.0). This permits unrestricted use, distribution, and reproduction in any medium, provided the original work is properly cited. 
Nkengfack et al. Global Epidemic Obesity 2013,

practices such as moderate physical activity, avoiding alcohol abuse and smoking etc., in the care and management of HIV infected persons $[15,16]$, will be a cost-effective strategy to improve nutritional status on a long term.

Thus this study aimed to describe the BMI of treatment naïve HIV patients in Yaoundé, Cameroon, and investigate the effects of nutritional education and lifestyle modification on the nutritional status of these patients. This paper presents the 6 months results of a 30 months on-going study.

\section{Methods}

\section{Study population and recruitment}

A cluster randomization by health facility was conducted between June 2010 and December 2012 in Yaoundé. This design was chosen to minimize the risk of contamination through exchange of information between the intervention and the control group during regular visits.

Inclusion criteria for health facilities (HF) included HF offering HIV care and/or treatment and a minimum of $100 \mathrm{HIV}$ patients registered. Inclusion criteria for patients included HIV patients aged between 20 and 72, with CD4 >350 cells/ $\mu \mathrm{l}$, viral load $<100,000 \mathrm{HIV}$ copies/ml and not receiving ARV at the beginning of the study. Patients were informed on study objectives and procedure and given the opportunity to ask questions before signing the informed consent. All study participants provided a signed informed consent before the study began.

Ethical approval was obtained from the national ethics committee of Cameroon (Authorisation $\mathrm{N}^{\circ} 106 / \mathrm{CNE} / \mathrm{DNM} / 08$ ), the Institutional Review Board of the Cameroon Baptist Health Unit ( $N^{\circ}$ IRB2010-02), and the Ministry of Public Health in Cameroon (Division de la Recherche Opérationnelle en Santé (DROS)) (Authorisation Administrative de Recherche $\left.\mathrm{N}^{\circ} 631-0211\right)$.

\section{Procedure \\ Intervention phase}

During this phase, participants in the intervention group received the HIV-Care-Program lasting 3 hours every week over six months. The HIV-Care-Program consisted of:

\section{Individual counselling}

Participant's nutritional status, nutritional need and nutritional knowledge were assessed using a 3-day dietary record, a food frequency questionnaire (FFQ) and self-administered questionnaires. Individual counselling took place during the first 2 weeks of the intervention phase and counselling duration was 30 minutes/participant. Later, the intervention group of 100 participants was divided into 6 groups (16-20 participants/group) for group counselling.

\section{Group counselling: Group counselling included the following lessons}

HIV and Nutrition: Effect of HIV on immune system, effects of HIV on nutritional status, nutritional needs of HIV patients, composition of a balanced diet (emphasis was put on the consumption of " 5 a day" intake of fruits and vegetables, high intake of carbohydrate, high intake of protein of plant origin e.g., kidney beans, soy bean etc., low intake of fat, high intake of dairy products and water), "One dollar shopping" (aimed to help participants to be able to buy the right food even with limited financial resources), malnutrition (causes of malnutrition, use of nutrition to reduce effects of malnutrition), nutrition and ARV (interaction between food and ARV) and food preservation (adequate food preservation methods and consequences on nutrient content of food). Lessons were based on WHO guidelines [17-19].

HIV and Hygiene: Including personal hygiene, food and water hygiene and hygiene of the home (kitchen, toilet) [17].

Coping with stigma and discrimination: How to reconcile ones' situation with one's self, reconciling with others and reconciling with the society. Coping strategies included problem focused (e.g., joining a support group, getting counselling etc.) and emotion-focused strategies (avoidance of problem, optimism, religion etc.) [20].

Physical activity: Participants were advised to practice moderate physical activity (PA). Moderate PA was defined as 25-30 minute walk per day, also equivalent to $2500-3000$ steps in 30 minutes/ day on level land [21,22].

Lessons were accompanied by practical activities such as shopping tours in local markets (participants were advised on when to go for food shopping, quality of good food e.g., fruits and vegetables), cookery seminars on regional food (participants were provided with practical guidelines for effective washing of fruits and vegetables before preparation, minimizing nutrient loss when cooking vegetables and local preparation of soy milk etc.). Workshops on healthy lifestyle were provided through role play on the use of condoms, reducing cigarette and alcohol intake. Food for cookery seminars and tools for workshops were provided by study team.

Transport cost was refunded for participants who attended the counselling meetings and routine visits. Group counselling took place once a week over six months and meeting duration was 3 hours per group. During this phase, facilitators were trained according to a standardized curriculum, to lead the refresher sessions and support groups.

Participants in the control group were subjected to the general practitioner's choice of therapy (usual-care). In Cameroon, the usual care treatment for HIV/AIDS patients consists of periodic CD4 cell count and viral load check-up and provision of family planning accessories and condoms.

\section{Follow-up phase}

Participants in the intervention group received refresher sessions, lasting 3 hours every 2 weeks for 12 months and subsequently 3 hours every month for 12 months. All refresher sessions were conducted by trained facilitators, assisted by the study dietician and coordinator. 


\section{Sample size considerations}

The study was designed to detect a difference of $20 \%$ between the groups with a between cluster variance of 0.005 . Five health facilities recruiting an average of 60 patients, given $80 \%$ power and a $10 \%$ drop out rate would yield 135 patients per group. A difference of $20 \%$ was chosen as an estimate of clinically relevant change. After four months of recruitment, instead of one month as previously scheduled, only an average of 100 participants were enrolled in each group, instead of 135. For these reasons and others, relating to funding the study management decided to begin the intervention with a sample size of 100/101 study participant per group.

\section{Randomization and masking of treatment allocation}

Prior to study start, health facilities were assessed to determine size, number of HIV patient available, then randomly assigned to the intervention or control group, using a computer generated random list. This was done by an investigator not involved in the study, and stratification was done by health facilities size. The code was held only by the study coordinator and data bank administrator during the trial. To assure blinding, staff responsible for measuring and collecting health and sociodemographic outcomes and study clinicians were unaware of group allocation and not employed by health facility.

\section{Outcome measurements and data collection}

Primary outcome was change in initial BMI and serum albumin after 6 months.

Anthropometric measurements: Height was measured to the nearest centimetre with a standiometer and weight to the nearest $0.1 \mathrm{~kg}$ with a standard scale (Seca 216/792, Hamburg, Germany).

Biomedical and clinical assessment: Albumin was measured using the Bromocresol green (BCG) colorimetric method. CD4 cell count was measured using the flow cytometry (FacsCalibur [Becton Dickinson Immunocytometry system (BDIS), San Jose, CA, USA]).

Nutritional assessment: A 3-day dietary record including all food and beverages consumed, portion size and method of preparation was used to assess nutrient intake. Nutrient intake was later analysed using a Nutrition Database (Ernährungsanamnese-Beratungs-Informations-System EBIS 2011 (University of Hohenheim, Stuttgart, Germany)). A food frequency questionnaire grouped in 9 main categories (meat, fish, vegetables, fruits, starchy food, dairy products, fats and oils, local dishes, miscellaneous), was used to assess the frequency of food intake.

Questionnaire: A self-administered questionnaire included demographic information (age, educational level, occupation, and socioeconomic status), physical activity, alcohol and cigarette intake, as well as personal evaluation of program relevance.

Assessments of all parameters and collection of data were conducted at baseline and after 6 months in the intervention and control group.
Compliance was based on the number of weekly meetings attended by each participant, in the intervention group.

\section{Data analysis}

Statistical analysis was carried out using SPSS statistics 20 (IBM Corporation, 2011). BMI was calculated from weight $(\mathrm{kg})$ and height $\left(\mathrm{m}^{2}\right)$ and categorized as: underweight $(\mathrm{BMI}<18.5)$, normal weight $(18.5 \leq \mathrm{BMI} \leq 24.9)$, overweight $(25 \leq \mathrm{BMI} \leq$ 29.9) and obese (BMI $\left.\geq 30 \mathrm{~kg} / \mathrm{m}^{2}\right)$. BMl was used to estimate the prevalence of underweight, normal weight and overweight/ obesity. Baseline characteristics between the intervention and the control group were analysed using Univariate Analysis of Covariance (ANCOVA) for continuous variables and chi-square test for categorial variables. After 6 months, BMI and albumin between the intervention and the control group were analysed using Univariate ANCOVA, adjusting for clusters and baseline variables. Finally we also carried out a correlation analysis to see if BMI and albumin after 6 months correlated with baseline CD4 cell count and if albumin correlated with BMI after 6 months. Correlation analysis was done each time for both groups together and then separately, unadjusted using Pearson correlation and partial correlation controlling for clusters.

All analysis were conducted according to the intentionto-treat population and values were significant at $p<0.05$ without adjusting for multiple testing.

\section{Results}

All five health facilities completed the trial (Figure 1). 201 participants were enrolled and 190 evaluated for outcomes after 6 months. Ten (10\%) study participants in the intervention were lost to follow-up and one (1\%) in the control group. More than $90 \%$ of the participants in the intervention group judged the program as being relevant and useful for their health.

Differences at baseline between the groups were not statistically relevant with respect to age, sex, weight, BMI, CD4 count (Table 1). Albumin level between the intervention and the control group was significantly different at baseline $(P<0.001)$. Average weekly alcohol intake was 13 glasses of alcoholic beverages in the intervention group compared to 7 glasses in the control group. After 6 months average weekly alcohol intake dropped in the intervention group to 8 glasses of alcoholic beverages in the intervention group compared to the control group where no changes was observed. Excluding calcium, nutrient intake between the groups recorded from the 3-day dietary record at baseline was higher than recommended daily allowance (RDA) (Table 2).

After 6 months, the difference in BMI between the intervention and the control group was not statistically significant (Table 3). Also, the prevalence of underweight was 2(2\%), normal weight $35(38.8 \%)$, overweight $35(38.8 \%)$, obesity $18(20 \%)$ in the intervention group compared to the control group with under weight 6(6\%), normal weight 45(45\%), overweight 30(30\%)and obesity 19(19\%). Analysing the intervention and the control 


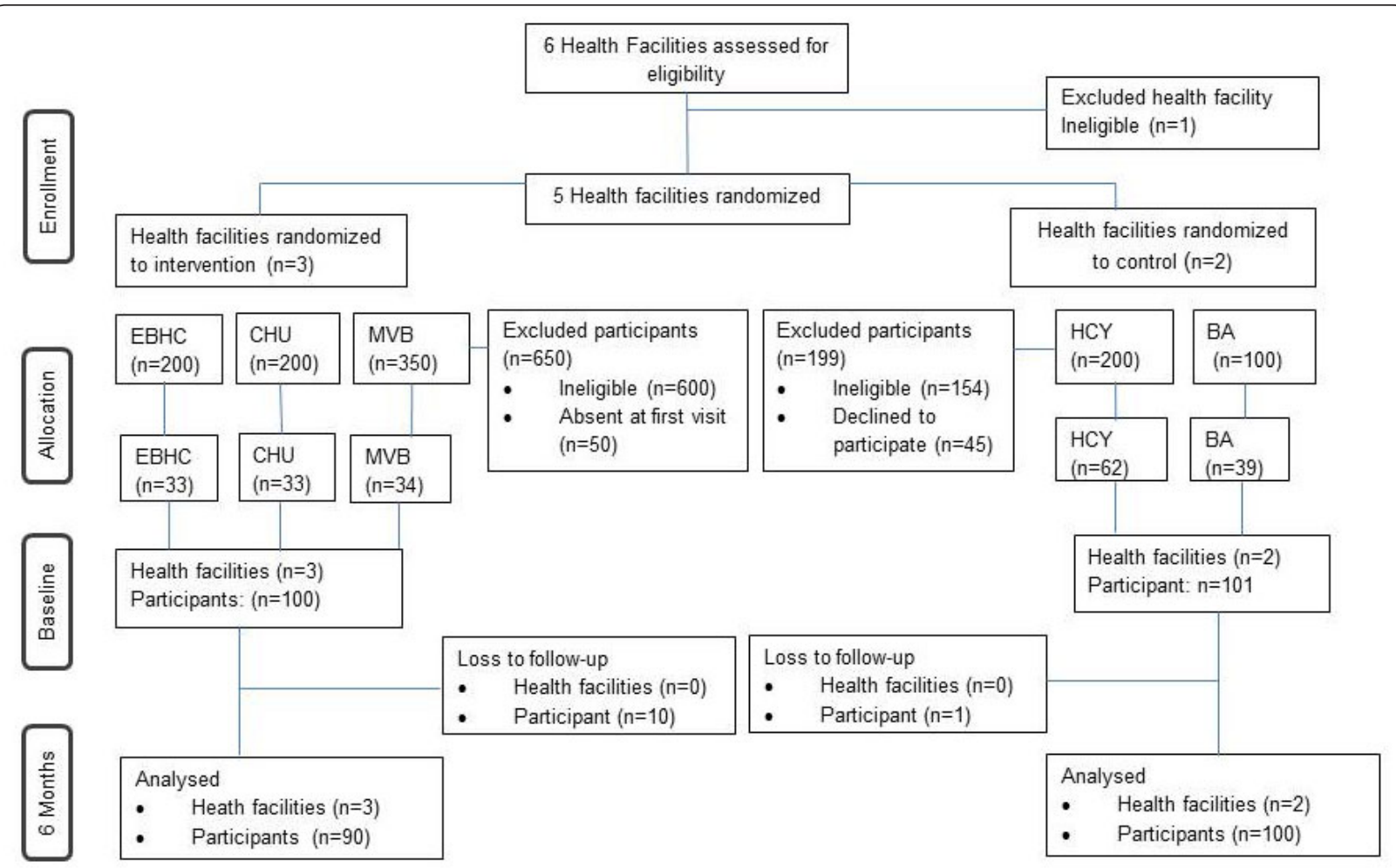

Figure 1. The flow diagram of clusters and individuals through the cluster randomized trial. Etoug-ebe Baptist Health Centre (EBHC), Mvog-besi Hospital (MVB), Centre Hospitalier Universitaire (CHU), Hospital Central Yaounde (HCY), Biyem-Assi Hospital (BA).

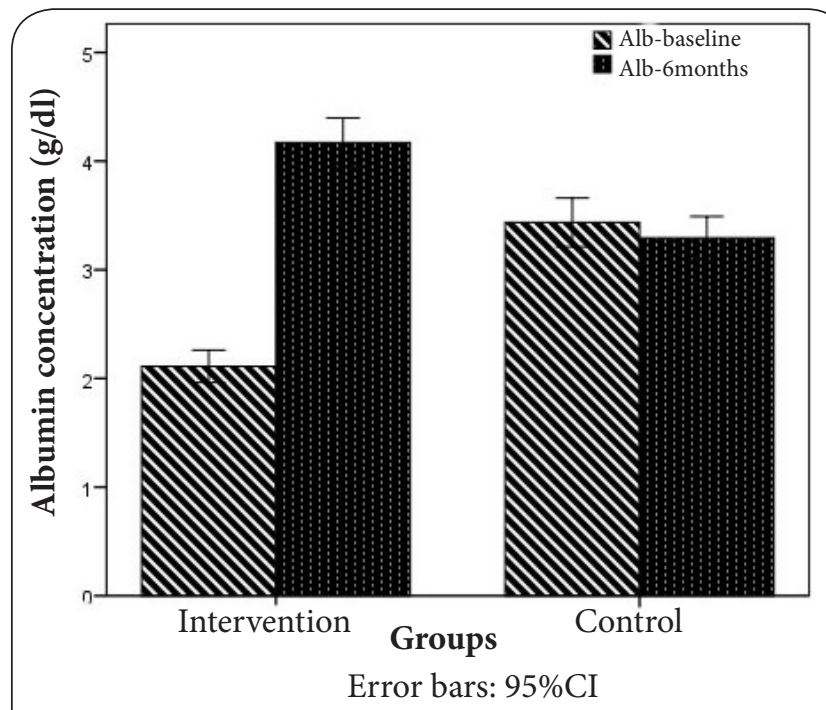

Figure 2. Changes in albumin concentration between the intervention and control group at baseline and after 6 months.

Bars represent albumin concentrations $(\mathrm{g} / \mathrm{dl})$ per group Intervention group

- Baseline albumin concentration: Bars with white background and black lines going from left to right. - 6 months albumin concentration: Bars with black background and white dotes. group combined and then separely showed no correlation between BMI after 6 months and baseline CD4, with and without adjusting for clusters.

Serum albumin after 6 months increased from $2.1 \mathrm{~g} / \mathrm{dl} \mathrm{Cl} 95 \%$ $(1.8,2.4)$ to $4.2 \mathrm{~g} / \mathrm{dl} \mathrm{Cl} 95 \%(3.8,4.5)$ in the intervention group compared to a decrease from $3.4 \mathrm{~g} / \mathrm{dl} \mathrm{Cl} 95 \%(3.2,3.7)$ to $3.3 \mathrm{~g} /$ dl Cl 95\% (3.0, 3.6). The difference between the intervention and control group after 6 months was statistically significant (Figure 2). In the intervention group, participants with albumin level above $3.5 \mathrm{~g} / \mathrm{dl}$ increased from 4 participants at baseline to 64 after 6 months compared to the control group with a decrease from 38 participants at baseline to 29 after 6 months.

No correlation was observed between albumin after 6 months and baseline CD4 for both groups combined or separate. A tendency for albumin to correlate with BMI ( $r=$ $0.146, P=0.055$ ) was observed for both groups combined but no correlation was observed for the separate groups after 6 months. Also a partial correlation was observed between albumin and BMI after 6 months, after adjusting for clusters ( $r=0.158, P=0.037)$.

Analysis of the 3-day dietary record after 6 months showed that calorie intake $(P=0.013)$, protein intake $(P<0.001)$ and fat intake ( $P=0.004)$ (Table 4) differed significantly between the groups. Carbohydrate intake did not differ significantly between the groups ( $P=0.854)$, (Table 4$)$. 
Nkengfack et al. Global Epidemic Obesity 2013,

http://www.hoajonline.com/journals/pdf/2052-5966-1-5.pdf

doi: $10.7243 / 2052-5966-1-5$

Table 1. Baseline characteristics of study participants: Clusters, Demographic, Anthropometric and Clinical parameters.

\begin{tabular}{|c|c|c|c|}
\hline Characteristics & $\begin{array}{l}\text { Intervention group } \\
(\mathrm{n}=100)\end{array}$ & $\begin{array}{l}\text { Control group } \\
(\mathrm{n}=101)\end{array}$ & P-value \\
\hline \multicolumn{4}{|l|}{ Cluster size n (\%) } \\
\hline${ }^{1} \mathrm{EBHC}$ & $33(16.4)$ & $0(0)$ & \\
\hline${ }^{2} \mathrm{CHU}$ & $33(16.4)$ & $0(0)$ & \\
\hline${ }^{3} \mathrm{MVB}$ & $34(16.9)$ & $0(0)$ & \\
\hline${ }^{4} \mathrm{HCY}$ & $0(0)$ & $62(30.8)$ & \\
\hline${ }^{5} \mathrm{BA}$ & $0(0)$ & $39(19.4)$ & \\
\hline \multicolumn{4}{|l|}{ Demographic parameters } \\
\hline Age (years) mean \pm SD & $33.0 \pm 8.3$ & $34.4 \pm 10.0$ & 0.224 \\
\hline \multicolumn{4}{|l|}{ Sex n (\%) } \\
\hline Male & $31(31.0)$ & $35(34.7)$ & \\
\hline Female & $69(69.0)$ & $66(65.3)$ & \\
\hline \multicolumn{4}{|l|}{ Education n (\%) } \\
\hline None & $8(8.0)$ & $16(15.8)$ & \\
\hline Primary & $36(36.0)$ & $32(31.7)$ & \\
\hline Secondary & $37(37.0)$ & $38(37.6)$ & \\
\hline University & $19(19.0)$ & $14(13.9)$ & \\
\hline No response & 0 & $1(1.0)$ & \\
\hline \multicolumn{4}{|l|}{ Employment n (\%) } \\
\hline Yes & $37(37.0)$ & $29(28.7)$ & \\
\hline no & $59(59.0)$ & $69(68.3)$ & \\
\hline No response & $4(4.0)$ & $3(3.0)$ & \\
\hline \multicolumn{4}{|l|}{${ }^{6}$ Monthly income n (\%) } \\
\hline$<100.000$ & $58(58.0)$ & $36(35.6)$ & \\
\hline $100.000-200.000$ & $13(13.0)$ & $5(5.0)$ & \\
\hline$>200.000$ & $5(5.0)$ & $3(3.0)$ & \\
\hline No response & $24(24.0)$ & $57(56.4)$ & \\
\hline \multicolumn{4}{|c|}{ Clinical and anthropometrical parameters $($ mean \pm SD) } \\
\hline Weight (kg) & $70.1 \pm 13.0$ & $69.7 \pm 14.7$ & 0.849 \\
\hline Height $\left(\mathrm{m}^{2}\right)$ & $1.6 \pm 0.1$ & $1.7 \pm 0.1$ & 0.409 \\
\hline BMI $\left(\mathrm{kg} / \mathrm{m}^{2}\right)$ & $26.1 \pm 4.2$ & $25.9 \pm 5.0$ & 0.798 \\
\hline CD4 (cells/ $\mu \mathrm{l})$ & $603.8 \pm 213.6$ & $555.2 \pm 198.2$ & 0.081 \\
\hline Albumin (g/dl) & $2.1 \pm 1.0$ & $3.4 \pm 1.1$ & $<0.001$ \\
\hline
\end{tabular}

${ }^{1}$ (EBHC), Etoug-ebe Baptist health Centre, ${ }^{2}(\mathrm{CHU})$ Centre Hospitalier Universitaire, ${ }^{3}$ (MVB) Mvog-besi Hospital, ${ }^{4}(\mathrm{HCY})$, Hospital Central Yaoundé, ${ }^{5}$ (BA) Biyem-Assi Hospital, ${ }^{6} 100$ FRS $\mathrm{CFA}=165 €, \mathrm{SD}=$ standard deviation, Statistical estimates were based on Univariate ANCOVA and a Chi-square test.

\section{Compliance}

Compliance was good with about $65 \%$ participation at each meeting over the 6 months intervention period.

\section{Discussion}

Besides the long known wasting syndrom observed in HIV patients recent studies indicate changes in the nutritional profile of HIV infected patients $[\mathbf{1 0 , 1 1 , 2 3 , 2 4 ]}$. In this study, authors observed that more than $50 \%$ of the study participants in both the intervention and control group were overweight/ obese at baseline (Table 2). Other investigators have made similar observations with HIV patients having rates of over-
Table 2. Baseline Characteristics: Lifestyle.

\begin{tabular}{|c|c|c|c|c|}
\hline Characteristics & $\begin{array}{l}\text { Intervention group } \\
(\mathrm{n}=100)\end{array}$ & $\begin{array}{l}\text { Control group } \\
(n=101)\end{array}$ & RDA $^{1}$ & P-value \\
\hline \multicolumn{5}{|c|}{ Nutrition $($ mean $\pm S D)$} \\
\hline Energy (Kcal) & $2114.9 \pm 496.9$ & $2457.5 \pm 966.1$ & $2127.5^{2}$ & 0.002 \\
\hline Protein (g) & $68.1 \pm 22.2$ & $84.8 \pm 44.8$ & 57.1 & 0.001 \\
\hline Fat (g) & $81.7 \pm 32.4$ & $101.2 \pm 49.9$ & 65.6 & 0.002 \\
\hline Carbohydrate (g) & $266.5 \pm 70.8$ & $288.8 \pm 123.1$ & 276.1 & 0.124 \\
\hline Vitamin A $(\mu \mathrm{g})$ & $1974.8 \pm 1255.4$ & $2907.1 \pm 4381.3$ & 800.0 & 0.044 \\
\hline B-Carotene (mg) & $10.6 \pm 7.6$ & $9.6 \pm 5.6$ & 8.0 & 0.321 \\
\hline Vitamin C (mg) & $143.2 \pm 100.2$ & $159.8 \pm 128.1$ & 100.0 & 0.318 \\
\hline Vitamin E (mg) & $11.8 \pm 5.2$ & $17.9 \pm 14.1$ & 12.0 & 0.001 \\
\hline Calcium (mg) & $479.5 \pm 253.5$ & $482.2 \pm 221.8$ & 1000.0 & 0.939 \\
\hline Zinc (mg) & $8.8 \pm 3.2$ & $9.9 \pm 5.2$ & 12.0 & 0.064 \\
\hline Iron (mg) & $12.2 \pm 4.0$ & $14.2 \pm 5.8$ & 15.0 & 0.005 \\
\hline \multicolumn{5}{|c|}{ Alcohol intake n (\%) } \\
\hline Yes & $41(41)$ & $45(44.6)$ & & \\
\hline No & $53(53)$ & $27(26.7)$ & & \\
\hline No response & $6(6)$ & $29(28.7)$ & & \\
\hline \multicolumn{5}{|c|}{ Smoked in the past $\mathrm{n}(\%)$} \\
\hline Yes & $9(9)$ & $7(6.9)$ & & \\
\hline No & $79(79)$ & $69(68.3)$ & & \\
\hline No response & $12(12)$ & $25(24.8)$ & & \\
\hline \multicolumn{5}{|c|}{$\begin{array}{l}\text { Physical activity in the } \\
\text { past } n(\%)\end{array}$} \\
\hline Yes & $68(68)$ & $61(60.4)$ & & \\
\hline No & $20(20)$ & $8(7.9)$ & & \\
\hline No response & $12(12)$ & $32(31.7)$ & & \\
\hline \multicolumn{5}{|l|}{ BMI $\left(\mathrm{kg} / \mathrm{m}^{2}\right)$ n (\%) } \\
\hline$<18.5$ & $2(2)$ & $2(1.9)$ & & \\
\hline $18.5-24.9$ & $40(40)$ & $44(43.5)$ & & \\
\hline $25-29.9$ & $39(39)$ & $34(33.6)$ & & \\
\hline$>30$ & $19(19)$ & $21(20.8)$ & & \\
\hline \multicolumn{5}{|c|}{ Albumin (g/dl) n (\%) } \\
\hline$<3.5 \mathrm{~g} / \mathrm{dl}$ & $96(96)$ & $63(62.4)$ & & \\
\hline$\geq 3.5 \mathrm{~g} / \mathrm{dl}$ & $4(4)$ & $38(37.6)$ & & \\
\hline
\end{tabular}

${ }^{1} \mathrm{RDA}$ required daily allowance, $(\mathrm{SD})$ standard deviation

${ }^{2}$ Energy value for HIV positive patients increase by $10 \%$ compared to HIV negatives, thus $(1934.1+193.4=2127.5$ (RDA)). Statistical estimates were based on ANCOVA and a Chi-square test.

weight/obesity as high as that of the general population $[\mathbf{2 3}, \mathbf{2 5}]$. Previously overweight/obesity in HIV/AIDS was associated with HAARTS intake $[\mathbf{8}, \mathbf{2 6}]$. Recent evidence exists that HAARTS represents just a modest contribution to weight gain in HIV patients and that many HIV patients are already overweight/ obese before HAARTS initiation [11]. A possible reason for this tendency could be lack of knowledge on adequate nutrition [10]. Some authors predict that this trend observed could be a conscious stategy adopted by HIV patients - through intake of high-calorie diet and avoiding physical exertion - to avoid stigma and discrimination associated with being slim $[10,23]$. Our observations somehow confirms this assumption, since macronutrient intake of study participants in both groups were higher than the RDA (Table 2). These changes in the nutritional profile of HIV patients now present new challenges on HIV 
Nkengfack et al. Global Epidemic Obesity 2013,

http://www.hoajonline.com/journals/pdf/2052-5966-1-5.pdf

doi: $10.7243 / 2052-5966-1-5$

Table 3. Comparison of various parameters between the Intervention and the Control group at baseline and after 6 months.

\begin{tabular}{lllllc}
\hline & \multicolumn{2}{c}{ Intervention group } & \multicolumn{2}{c}{ Control group } \\
\hline Parameters & Baseline $(\mathbf{n}=\mathbf{1 0 0})$ & $\mathbf{6 ~ m o n t h s ~}(\mathbf{n = 9 0 )}$ & Baseline $(\mathbf{n = 1 0 1})$ & $\mathbf{6}$ months $(\mathbf{n = 1 0 0 )}$ & P-value \\
\hline Weight $(\mathrm{kg})$ & $70.1(65.3,74.8)$ & $71.5(66.4,76.6)$ & $69.7(65.4,73.3)$ & $67.5(63.6,71.6)$ & 0.059 \\
BMI $\left(\mathrm{kg} / \mathrm{m}^{2}\right)^{*}$ & $26.1(24.5,27.6)$ & $26.6(24.9,29.0)$ & $25.8(24.5,27.1)$ & $25.1(23.7,26.4)$ & 0.088 \\
Albumin $(\mathrm{g} / \mathrm{dl})^{*}$ & $2.1(1.8,2.4)$ & $4.2(3.8,4.5)$ & $3.4(3.2,3.7)$ & $3.3(3.0,3.6)$ & $<0.001$ \\
CD4 $(\mathrm{cells} / \mu \mathrm{l})^{*}$ & $603.6(533.6,673.6)$ & $557.3(477.9,636.8)$ & $561.4(503.4,619.5)$ & $432.4(370.6,494.3)$ & 0.003
\end{tabular}

*Values shown are Mean and 95\% confidence interval in brackets (CI)

P-values are based on Univariate ANCOVA after 6 months, adjusted for baseline CD4 and clusters.

Table 4. Comparison of macronutrient intake between the intervention and the control group at baseline and after 6 months.

\begin{tabular}{llllll}
\hline \multicolumn{4}{c}{ Intervention group } & \multicolumn{2}{c}{ Control group } \\
\hline Characteristics & Baseline $(\mathbf{n}=\mathbf{1 0 0})$ & $\mathbf{6}$ months $(\mathbf{n}=\mathbf{9 0})$ & Baseline $(\mathbf{n = 1 0 1})$ & $\mathbf{6}$ months $(\mathbf{n}=\mathbf{1 0 0})$ & P-value \\
\hline Energy $(\text { Kcal })^{*}$ & $2115.3(1966.1,2264.5)$ & $2151.7(2004.8,2298.6)$ & $2238.7(1729.6,2747.9)$ & $2803.2(2314.5,3291.9)$ & 0.013 \\
Protein $(\mathrm{g}){ }^{*}$ & $68.1(61.3,75.0)$ & $72.7(66.9,78.4)$ & $74.0(50.7 .97 .3)$ & $124.7(105.5,143.8)$ & $<0.001$ \\
Fat $(\mathrm{g}){ }^{*}$ & $81.7(73.5,89.9)$ & $81.8(74.2,89.3)$ & $99.0(70.9,127.0)$ & $121.1(96.0,146.2)$ & 0.004 \\
Carbohydrate $(\mathrm{g})^{*}$ & $266.6(246.7,286.3)$ & $289.1(257.4,320.8)$ & $253.5(186.3,320.9)$ & $299.3(193.9,404.7)$ & 0.854 \\
\hline
\end{tabular}

*Values shown are mean and 95\% confidence interval in brackets (CI)

P-values is based on Univariate ANCOVA after 6 months, adjusting for baseline BMI and clusters

health care providers and suggests that qualified dieticians be involved in the care and management of HIV/AIDS.

Several investigators have shown that adequate nutrition and modified lifestyle associated with or without education and counseling can improve nutritional status both during stable treatment free period and during severe episodes of the infection $[\mathbf{2}, \mathbf{1 2}, \mathbf{2 7}, \mathbf{2 8}]$. In this study, the authors also investigated the effects of nutritional education and lifestyle modification on the nutritional status of treatment naïve HIV patients in Yaoundé, Cameroon. Based on previous results, a majority of ARV naive patients in resource limited settings are known to be underweight $[3,4,7]$. However, in this study, the BMI of study participants after 6 months intervention increased by $1.9 \%$ in the intervention group after 6 months compared to $3 \%$ decrease in the control group. Although the difference between the groups was not statistically significant, a possible reason for the slight increase in BMI in the intervention group compared to the control group could be due to the moderate rate of physical activity practiced by the study participants. Studies have shown that the current physical activity guideline for adults of 25-30 minutes of moderate intensity physical activity daily would limit health risks for chronic diseases but would likely be insufficient for preventing weight gain $[21,22]$. Moreover, even if evidence exist that mild-to-moderate obesity is associated with reduced rates of mortality in HIV patients $[29,30]$, its later consequences on health are far more severe than advantages $[\mathbf{8}, \mathbf{1 1}, \mathbf{2 4}]$.
Although albumin is not a specific marker of HIV infection, low serum albumin in HIV pateints has been identified as an important indicator of malnutrition and severity of the HIV infection $[31,32]$. In this study, after 6 months a statistically significant increase in the albumin concentration was observed in the intervention group compared to a decrease in the control group. A similar observation was made by Marques and coworkers with nutritional supplements in HIV patients [33]. A possible reason for the high increase in albumin level observed in the intervention group could be related to the intervention. However, considering the higher nutrient intakes in the control group compared to the intervention group, we would have expected a greater increase in the control group (Table 3 ). We therefore assume that besides nutrition, albumin level may be influenced by other clinical factors such as CD4. In this study we observed a decrease in CD4 in both groups after 6 months. The rate at which CD4 dropped was higher in the control group compared to the intervention group (Table 3 ). The difference between the groups was statistically significant. Although no correlation was observed between albumin after 6 months and baseline CD4 count in our study, other investigators have observed a positive correlation between albumin and CD4 in HIV patients initiating ARV $[32,34,36,37]$. The fact that these patients were initiating ARV, indirectly indicate that they were at an advanced stage of the infection (i.e., CD4 counts below 350 cells/ $\mu \mathrm{l}$ ). This is contrary to our study participants who were at an early stage of infection 
(i.e., CD4 above 500 cells/ $\mu$ l) (Table 1).

It is known that HIV has a close relationship with nutritional status. However, it's impact on BMI is independent of the CD4 count $[\mathbf{2 6}, \mathbf{3 4}]$. This assumption was confirmed in our study by the absence of correlation between BMI after 6 months and baseline CD4. Shor-Posner and co-workers made a similar observation in a longitudinal study with HIV-1 drug users [35].

Meanwhile, a tendency for serum albumin and BMI after 6 months to correlate was observed in both groups combined. Dusingize and co-workers observed a positive correlation between albumin and BMI with HIV positive women having CD4 cells/ $\mu$ l below 200 cells/ $\mu$ l [37]. These results suggest that, at an early stage of the HIV infection, albumin levels may be influenced by other clinical manifestations other than nutritional status. Thus, the ability for albumin to be used as a specific marker of malnutrition is limited [31,37].

Limitations and strengtwhs: This study is limited by the fact that the nutrient content of the food consumed were not evaluated directly, but documented from a 3-day dietary record. Also, the fact that the nutrient intake was documented after several months (baseline and 6 months) for both groups also limits the ability to observe small changes in nutrient intake. Future investigations should focus on documenting nutrient intake on a weekly basis.

The limited number of health facilities in our study influenced the ability to detect significant changes. A larger sample size with more health facilities would have permitted more precise assessment of smaller changes between the intervention and the control groups. The subjective approach used to collect data was based on self-report. Here participants' response may be inaccurate; reflecting what participants feel the investigator may wish to hear [38]. However, the prospective collection of our dietary food record, provided a more precise assessment of dietary habits compared to the $24 \mathrm{~h}$ food recall, associated with recall bias. Also, the involvement of both sexes makes these results more reliable in terms of generalizing our results to the general population.

\section{Conclusion}

Our results show that a nutritional education and lifestyle modification intervention in a resource limited country is possible and can improve serum albumin after 6 months intervention. The high prevalence of overweight/obesity observed draws the attention of health care providers to involve dieticians in the care and management of HIV. Also future nutritional interventions should focus not only on strategies to increase weight, but also on optimising weight, respectively weight reduction in treatment naïve HIV patients. Long-time effects of the intervention after 30 months will be documented in a future article.

\section{Competing interests}

The authors declare that they have no competing interests.

\section{Authors' contributions}

\begin{tabular}{|l|c|c|c|c|}
\hline Authors' contributions & GN & JT & JN & HE \\
\hline Research concept and design & $\checkmark$ & $\checkmark$ & $\checkmark$ & $\checkmark$ \\
\hline Collection and/or assembly of data & $\checkmark$ & -- & -- & $\checkmark$ \\
\hline Data analysis and interpretation & $\checkmark$ & -- & -- & $\checkmark$ \\
\hline Writing the article & $\checkmark$ & -- & -- & $\checkmark$ \\
\hline Critical revision of the article & $\checkmark$ & $\checkmark$ & $\checkmark$ & $\checkmark$ \\
\hline Final approval of article & $\checkmark$ & -- & -- & $\checkmark$ \\
\hline Statistical analysis & $\checkmark$ & -- & -- & -- \\
\hline
\end{tabular}

\section{Acknowledgement}

The investigators would like to thank the study staff and subjects for their participation in this project. This work was supported by the "Investitions fonds, University of Applied Sciences" Muenster, Germany. Additional funding was provided by "Gesellschaft der Foerderer Fachhochschule" Muenster, Germany. Material support was provided by Seca gmbH Hamburg, Partec Gorlitz, Franken gmbH Neuss and RWE Companius, Germany. Funding for a doctoral thesis was received from the Heinrich-BoellStiftung, Germany. The Cameroon Ministry of Public Health provided technical and scientific support during this work. The Etoug-Ebe Baptist Health Centre, the Faculty of Medicine and Biomedical Sciences Yaoundé I and Chantal Biya International Reference Centre provided access to their laboratories.

\section{Publication history}

Senior Editor: Alexandra Kautzky-Willer, Medical University of Vienna, Austria.

Received: 29-Aug-2013 Revised: 20-Oct-2013

Re-Revised: 02-Nov-2013 Accepted: 09-Nov-2013

Published: 28-Dec-2013

\section{References}

1. Byron E, Gillespie S and Hamazakaza P. Local perceptions of HIV risk and prevention in Southern Zambia. International Food Policy Research Institute. 2006; 2:339-44. I Article

2. Sinclair D, Abba K, Grobler L and Sudarsanam TD. Nutritional supplements for people being treated for active tuberculosis. Cochrane Database Syst Rev. 2011; CD006086. I Article I PubMed

3. Anabwani G and Navario P. Nutrition and HIV/AIDS in sub-Saharan Africa: an overview. Nutrition. 2005; 21:96-9. I Article I PubMed

4. Rollins N. Food Insecurity-A Risk Factor for HIV Infection. PLoS Med. 2007; 4:260. | Article

5. Paton NI, Sangeetha S, Earnest A and Bellamy R. The impact of malnutrition on survival and the CD4 count response in HIV-infected patients starting antiretroviral therapy. HIV Med. 2006; 7:323-30. | Article | PubMed

6. Kosmiski L. Energy expenditure in HIV infection. Am J Clin Nutr. 2011; 94:1677S-1682S. | Article | PubMed Abstract | PubMed Full Text

7. de Pee $S$ and Semba RD. Role of nutrition in HIV infection: review of evidence for more effective programming in resource-limited settings. Food Nutr Bull. 2010; 31:S313-44. I Article I PubMed

8. Koethe JR, Jenkins CA, Shepherd BE, Stinnette SE and Sterling TR. An optimal body mass index range associated with improved immune reconstitution among HIV-infected adults initiating antiretroviral therapy. Clin Infect Dis. 2011; 53:952-60. | Article I PubMed Abstract | PubMed Full Text

9. Johnson GP, Castrillón FJD and Ospina S. Alteraciones nutricionales en adultosinfectadospor el virus de la inmunodeficienciahumana. PerspectNutr Hum. 2004; 12:23-37.

10. Kuria EN. Food consumption and nutritional status of people living with HIV/AIDS (PLWHA): a case of Thika and Bungoma Districts, Kenya. 
Nkengfack et al. Global Epidemic Obesity 2013,

http://www.hoajonline.com/journals/pdf/2052-5966-1-5.pdf

doi: $10.7243 / 2052-5966-1-5$

Public Health Nutr. 2010; 13:475-9. | Article | PubMed

11. Tate T, Willig AL, Willig JH, Raper JL, Moneyham L, Kempf MC, Saag MS and Mugavero MJ. HIV infection and obesity: where did all the wasting go? Antivir Ther. 2012; 17:1281-9. | Article | PubMed Abstract | PubMed Full Text

12. Swaminathan S, Padmapriyadarsini C, Yoojin L, Sukumar B, Iliayas S, Karthipriya J, Sakthivel R, Gomathy P, Thomas BE, Mathew M, Wanke CA and Narayanan PR. Nutritional supplementation in HIV-infected individuals in South India: a prospective interventional study. Clin Infect Dis. 2010; 51:51-7. | Article | PubMed

13. Marcel AK, Ekali LG, Eugene S, Arnold OE, Sandrine ED, von der Weid D, Gbaguidi E, Ngogang J and Mbanya JC. The effect of Spirulina platensis versus soybean on insulin resistance in HIV-infected patients: a randomized pilot study. Nutrients. 2011; 3:712-24. | Article | PubMed Abstract | PubMed Full Text

14. Lunney KM, Jenkins AL, Tavengwa NV, Majo F, Chidhanguro D, lliff $P$, Strickland GT, Piwoz E, lannotti L and Humphrey JH. HIV-positive poor women may stop breast-feeding early to protect their infants from HIV infection although available replacement diets are grossly inadequate. $J$ Nutr. 2008; 138:351-7. | Article | PubMed

15. Anderson JW, Reynolds LR, Bush HM, Rinsky JL and Washnock C. Effect of a behavioral/nutritional intervention program on weight loss in obese adults: a randomized controlled trial. Postgrad Med. 2011; 123:205-13. | Article | PubMed

16. Nigatu T. Integration of HIV and noncommunicable diseases in health care delivery in low- and middle-income countries. Prev Chronic Dis. 2012; 9:E93. | Article | PubMed Abstract | PubMed Full Text

17. World Health Organization (WHO). How to integrate water, sanitation andhygiene into HIV programmes. WHO Library Cataloguing-inPublication Data. 2010. | Website

18. Food and Agriculture Organization (FAO). Living Well with HIV/AIDS: A manual on nutritional care and support for people living with HIV/AIDS. 2002. I Website

19. World Health Organization (WHO):“Energy and protein requirements, report of Joint FAO expert consultation," Technical Report Series 724, WHO, Geneva, Switzerland, 1985.

20. Collymore, J. Rooting out AIDS-related stigma and Discrimination Washington. Population Reference Bureau. 2002. | Article

21. Marshall SJ, Levy SS, Tudor-Locke CE, Kolkhorst FW, Wooten KM, Ji M, Macera CA and Ainsworth BE. Translating physical activity recommendations into a pedometer-based step goal: $\mathbf{3 0 0 0}$ steps in $\mathbf{3 0}$ minutes. Am J Prev Med. 2009; 36:410-5. | Article | PubMed

22. Saris WH, Blair SN, van Baak MA, Eaton SB, Davies PS, Di Pietro L, Fogelholm M, Rissanen A, Schoeller D, Swinburn B, Tremblay A, Westerterp KR and Wyatt $\mathrm{H}$. How much physical activity is enough to prevent unhealthy weight gain? Outcome of the IASO 1st Stock Conference and consensus statement. Obes Rev. 2003; 4:101-14. | Article | PubMed

23. Mariz Cde A, Albuquerque Mde F, Ximenes RA, Melo HR, Bandeira F, Oliveira TG, Carvalho EH, Silva AP and Miranda Filho Dde B. Body mass index in individuals with HIV infection and factors associated with thinness and overweight/obesity. Cad Saude Publica. 2011; 27:19972008. | Article | PubMed

24. Malaza A, Mossong J, Barnighausen T and Newell ML. Hypertension and obesity in adults living in a high HIV prevalence rural area in South Africa. PLoS One. 2012; 7:e47761. | Article | PubMed Abstract | PubMed Full Text

25. Hendricks KM, Mwamburi DM, Newby PK and Wanke CA. Dietary patterns and health and nutrition outcomes in men living with HIV infection. Am J Clin Nutr. 2008; 88:1584-92. | Article | PubMed Abstract I PubMed Full Text

26. Hughes SM, Amadi B, Mwiya M, Nkamba H, Mulundu G, Tomkins A and Goldblatt D. CD4 counts decline despite nutritional recovery in HIVinfected Zambian children with severe malnutrition. Pediatrics. 2009; 123:e347-51. | Article | PubMed

27. Fawzi WW, Msamanga GI, Kupka R, Spiegelman D, Villamor E, Mugusi F, Wei R and Hunter D. Multivitamin supplementation improves hematologic status in HIV-infected women and their children in Tanzania. Am J Clin Nutr. 2007; 85:1335-43. | Article | PubMed

28. Stambullian M, Feliu S and Slobodianik NH. Nutritional status in patients with HIV infection and AIDS. Br J Nutr. 2007; 98 Suppl 1:S140-3. | Article I PubMed

29. Vorster HH, Kruger A, Margetts BM, Venter CS, Kruger HS, Veldman FJ and Macintyre UE. The nutritional status of asymptomatic HIV-infected Africans: directions for dietary intervention? Public Health Nutr. 2004; 7:1055-64. | Article | PubMed

30. Shor-Posner G, Campa A, Zhang G, Persaud N, Miguez-Burbano MJ, Quesada J, Fletcher MA, Page JB and Baum MK. When obesity is desirable: a longitudinal study of the Miami HIV-1-infected drug abusers (MIDAS) cohort. J Acquir Immune Defic Syndr. 2000; 23:81-8. I Article | PubMed

31. Covinsky KE, Covinsky MH, Palmer RM and Sehgal AR. Serum albumin concentration and clinical assessments of nutritional status in hospitalized older people: different sides of different coins? J Am Geriatr Soc. 2002; 50:631-7. | Article | PubMed

32. Olawumi $\mathrm{HO}$ and Olatunji PO. The value of serum albumin in pretreatment assessment and monitoring of therapy in HIV/AIDS patients. HIV Med. 2006; 7:351-5. | Article | PubMed

33. Marques MRO, Kondo K and Moares HAB. HIV/AIDS e suportenutricional: efeitos da suplementaçãoalimentar sobre o estadonutricional de homens. Invenio. $2005 ; 8: 143-54$. | Pdf

34. Fufa $\mathrm{H}$, Umeta $\mathrm{M}$, Taffesse $\mathrm{S}$, Mokhtar $\mathrm{N}$ and Aguenaou H. Nutritional and immunological status and their associations among HIV-infected adults in Addis Ababa, Ethiopia. Food Nutr Bull. 2009; 30:227-32. I Article I PubMed

35. Ramakrishnan K, Shenbagarathai R, Kavitha K, Uma A, Balasubramaniam $R$ and Thirumalaikolundusubramanian $P$. Serum zinc and albumin levels in pulmonary tuberculosis patients with and without HIV. Jpn J Infect Dis. 2008; 61:202-4. | Article | PubMed

36. Feldman JG, Gange SJ, Bacchetti P, Cohen M, Young M, Squires KE, Williams C, Goldwasser P and Anastos K. Serum albumin is a powerful predictor of survival among HIV-1-infected women. J Acquir Immune Defic Syndr. 2003; 33:66-73. | Article | PubMed

37. Dusingize JC, Hoover DR, Shi Q, Mutimura E, Kiefer E, Cohen M and Anastos K. Association of serum albumin with markers of nutritional status among HIV-infected and uninfected Rwandan women. PLoS One. 2012; 7:e35079. | Article | PubMed Abstract | PubMed Full Text

38. Holtgraves T. Social desirability and self-reports: testing models of socially desirable responding. Pers Soc Psychol Bull. 2004; 30:161-72. | Article | PubMed

\section{Citation:}

Nkengfack G, Torimiro J, Ngogang J and Englert H. Effects of nutritional education and lifestyle modification on the nutritional status of HIV positive patients: results of a cluster randomized intervention over a period of six months. Glob Epidemi Obes. 2013; 1:5. http://dx.doi.org/10.7243/2052-5966-1-5 